\title{
Reaction and Geometrical Softening in Granitoid Mylonites
}

\author{
GRAHAM WILLIAMS and JOHN DIXON \\ Department of Geology, University College, P.O. Box 78, Cardiff CF1 1XL, \\ United Kingdom.
}

(Received June 24, 1981; in final form July 15, 1981)

\begin{abstract}
The microstructures of granitoid mylonites from Locquirec, N. Brittany; Ben Arnaboll, NW Scotland; and Cap de Creus, NE Spain show a similarity of development as a response to both geometric and reaction softening. A combination of these two softening processes leads to a concentration of deformation in the respective shear zones. Geometric softening leads to a rotation of quartz lattices for easy slip and is accompanied by dynamic recrystallization. Metamorphic reactions involving the breakdown of orthoclase and plagioclase feldspar to fine aggregates of muscovite plus quartz provide a secondary softening process which further concentrates deformation. These reactions indicate fluid mobility in the shear zones during deformation processes.
\end{abstract}

\section{INTRODUCTION}

According to the definition of White et al. (1980), mylonite may be regarded as "the rock produced in a ductile shear or fault zone which allows the zone to accommodate the imposed strain rate by dominantly ductile processes." It is implicit in this definition that mylonite is the material responsible for strain softening of shear zones, and this softening serves to localise deformation in these zones. Strain softening may be regarded, mechanically, as an increase in strain rate at a constant stress and temperature, and it may result from a number of processes (see White and Knipe, 1978; White et al., 1980; Poirier, 1980). Softening processes of interest in this paper are:

1) Geometrical or textural softening which has associated continual dynamic recrystallization.

2) Reaction softening. 
A combination of these processes leads to marked grain size reduction, and possibly a third softening process, a change in deformation mechanism may begin to operate after initial softening of a shear zone.

It is our aim in this paper to define the effects of reaction and geometrical softening in granitoid rocks sampled from ductile shear zones of three areas: Locquirec in N. Brittany, mylonitised Lewisian gneiss from the Arnaboll thrust of NW Scotland and the Cap de Creus area of NE Spain. All three areas have granitoid mylonites which show similar features, and in the case of the Locquirec samples it was possible to trace mylonite development from low to high strains $(\gamma>5)$ over a short distance which enabled detailed sampling and chemical analyses.

\section{MICROSTRUCTURES}

\section{Locquirec-Undeformed Granitoid}

At Locquirec in N. Brittany, there is an array of NE-SW trending shear zones which have preferentially formed at the contacts between granite bodies and Brioverian metasediments and volcaniclastics. This system of shear zones is thought to be related to the North Armorican Shear Zone which has undergone strike-slip deformation in a dextral sense (Watts and Williams, 1979; Watts, 1980).

A relict, equigranular igneous texture is preserved with orthoclase and albite/oligoclase showing reasonable crystal form (Figure 1a): Orthoclase contains small sericite intergrowths which are cleavage controlled and quartz exhibits lobate grain boundaries and undulatory extinction. Minor shears 50-100 $\mu \mathrm{m}$ wide are picked out by their quartz and muscovite mineralogy (Figure 1b), and sometimes a distinct granophyric texture is seen in least deformed granitoid. Over a distance of some 2 metres this rock shows a progressive sequence of recrystallization and grain size reduction from protomylonite through mylonite to ultramylonite (definitions of Sibson, 1977 used). This sequence of increasing strain and mylonitisation is illustrated in Figure $1 \mathrm{~b}, \mathrm{c}$ and $\mathrm{d}$.

\section{Locquirec ultramylonite}

Ultramylonite is a fine-grained well foliated rock which shows a pronounced stretching lineation. In thin section, the extremely fine grained dynamically recrystallized matrix of quartz and muscovite encloses oligoclase and quartz porphyroclasts (Figure 1d). The matrix is heterogeneous (Figure 1e), with coarser, quartz-rich bands (quartz $\sim 30 \mu \mathrm{m}$ ) and fine mica-rich bands (quartz $\sim 10 \mu \mathrm{m}$ ). New quartz grains tend to be equant in shape with smooth grain boundary morphologies, and in the mica-rich bands, well-formed (idio- 
Large quartz porphyroclasts (typically $700 \mu \mathrm{m}-1300 \mu \mathrm{m}$ ) are subelliptical or globular in shape and they range in frequency from 2 to 7 per $\mathrm{cm}^{2}$. These porphyroclasts contain a strong development of deformation bands, but they must be regarded as "hard" in that they resisted the bulk of the ductile deformation. A simple 2-D survey shows that most porphyroclasts have their $\mathrm{C}$-axes lying within or close to the XY plane marked by the strong mylonitic foliation in thin section (Figure 2). If basal slip was the active quartz slip system during deformation, then such unfavourably oriented grains, with basal planes at a high angle to the $\mathrm{XY}$ plane, may have remained as porphyroclasts as strain was developed (Tullis et al., 1973; Bouchez, 1977; Carreras et al., 1977).
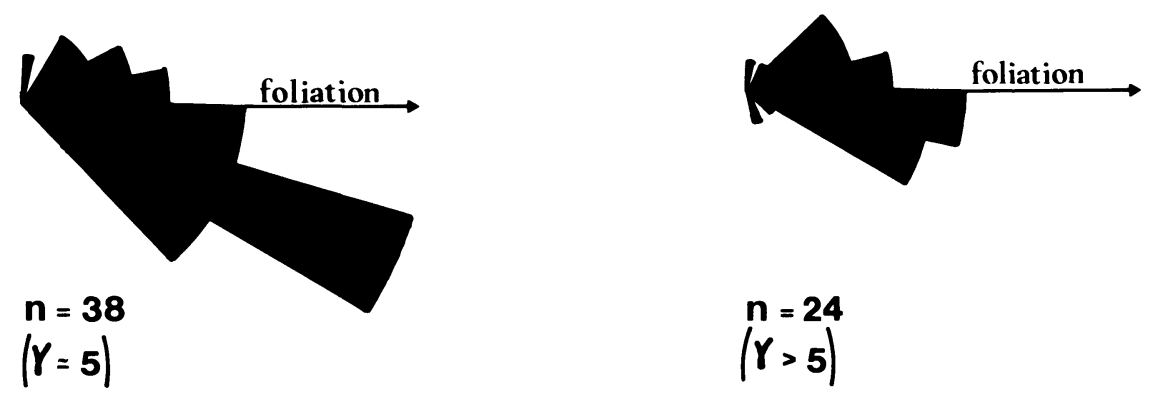

FIGURE 2 Orientation of c-axes of little deformed quartz grains measured in the plane of thin section for two Locquirec ultramylonites. Sections cut perpendicular to mylonitic foliation and parallel to stretching lineation (XZ sections). Shear strain values given in brackets.

\section{Arnaboll thrust protomylonite}

The Arnaboll thrust on Ben Arnaboll, Sutherland is a major thrust at the base of the Arnaboll Nappe (Coward, 1980; McClay and Coward, 1981). Granitoid Lewisian gneiss forming the base of the Arnaboll Nappe is thrust over Cambrian sediments and is intensely mylonitised in a ductile shear zone of about $20 \mathrm{~m}$ width immediately above the thrust. Fault rocks in this zone range from protomylonites to ultramylonites, but microstructures indicative of incipient strain softening are best seen in the protomylonites (Figure 3a).

In thin section, large relict clasts of oligoclase-andesine up to $8 \mathrm{~mm}$ in diameter are occasionally kinked, and are always intensely fractured (Figure $3 \mathrm{~b}, \mathrm{c})$. Microcline porphyroclasts ( $3 \mathrm{~mm}$ diameter) also show fracturing, and fracture gaps are infilled with quartz or fine muscovite mica. Microcline shows some edge replacement by muscovite. Quartz porphyroclasts ( $4 \mathrm{~mm}$ diameter) exhibit undulatory extinction and usually contain deformation lamellae (Figure 3e). Quartz shows core and mantle structure (White, 1976) with subgrains and dynamically recrystallized grains 10 to $30 \mu \mathrm{m}$ diameter, mantling 


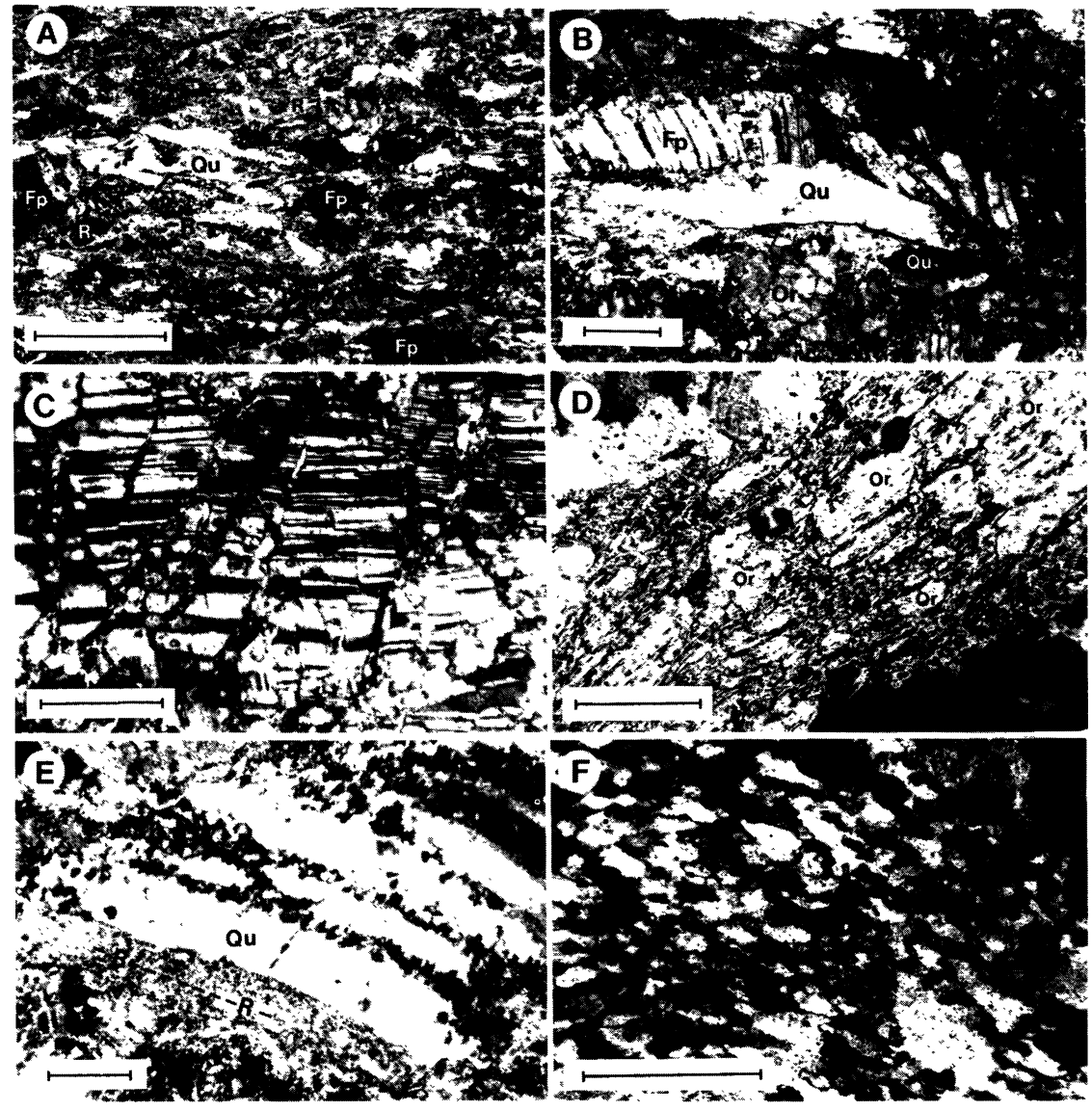

FIGURE 3. Photomicrographs of Arnaboll Nappe protomylonite (scale bar length in brackets). (a) protomylonite with anastomosing reaction softened zones- $\mathrm{R}(5 \mathrm{~mm})$; (b) plagioclase feldspar undergoing brittle fracture and rotation of fragments in a minor, reaction softened shear zone $(200 \mu \mathrm{m})$; (c) fractured plagioclase feldspar porphyroclast $(100 \mu \mathrm{m})$; (d) orthoclase feldspar (Or) undergoing reaction to muscovite along cleavages and at edges $(100 \mu \mathrm{m}) ;(\mathrm{e})$ quartz porphyroclast showing dynamic recrystallization preferentially concentrated along deformation lamellae $(100 \mu \mathrm{m})$; (f) dynamically recrystallized quartz grains with a marked shape fabric $(100 \mu \mathrm{m})$.

cores of quartz with undulatory extinction. Where dynamic recrystallisation has resulted in a large area of new quartz grains, they often have a shape fabric (Figure 3f). Orthoclase feldspar has undergone cleavage-controlled sericitization and white mica replaces feldspar at its boundaries (Figure 3d). A banded appearance is imparted on this rock by numerous, thin, high strain zones of fine muscovite plus quartz (Figure 3a). Quartz $(8-15 \mu \mathrm{m})$ has a straight boundary morphology and is pinned by a high proportion of idiomorphic muscovites, 8 to $20 \mu \mathrm{m}$ in length. 


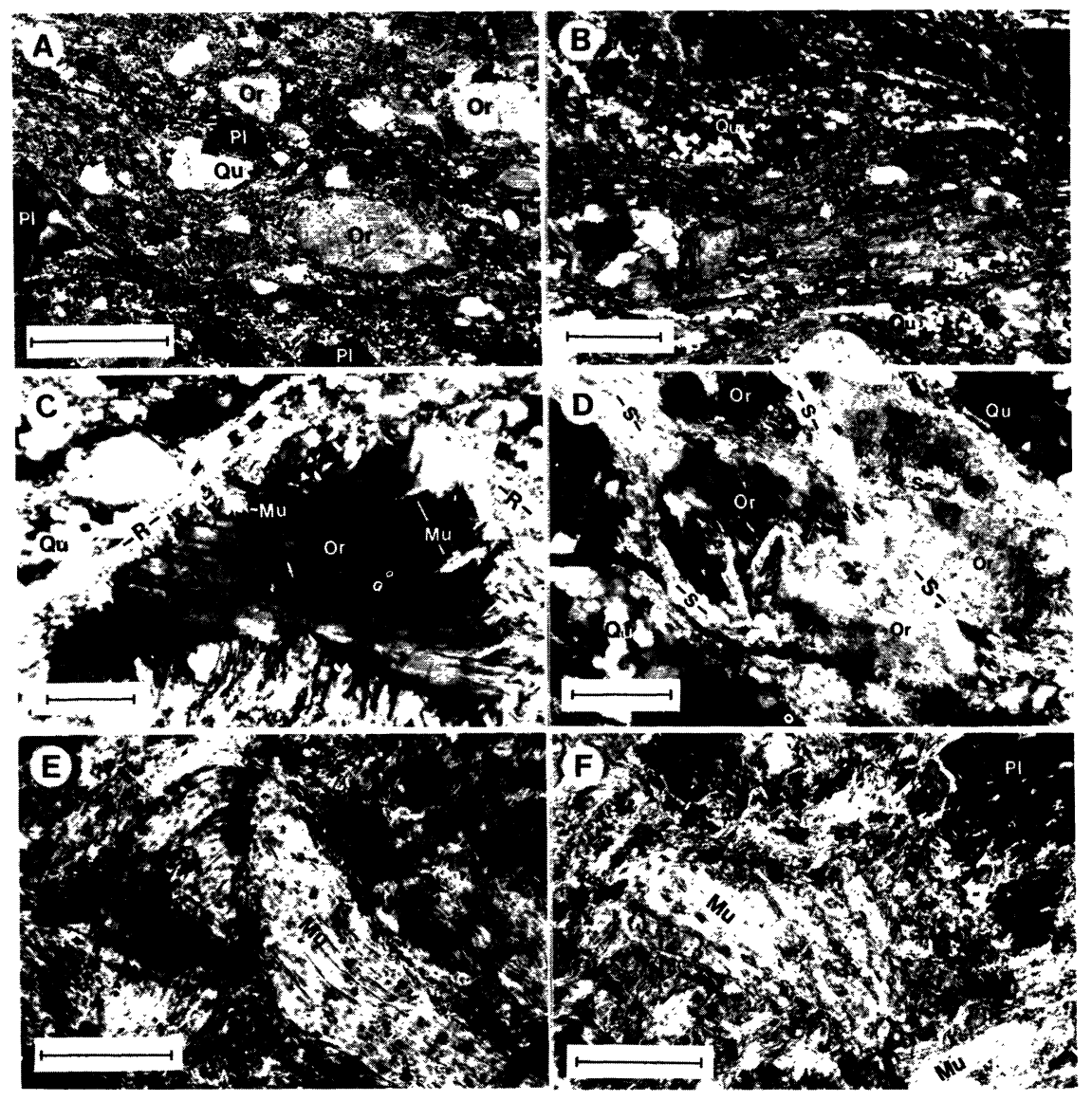

FIGURE 4 Photomicrographs of Cap de Creus mylonite (scale bar length in brackets). (a) mylonite showing porphyroclasts of quartz and feldspar set in a fine quartz plus muscovite matrix $(5 \mathrm{~mm})$; (b) detail of (a) showing bands of recrystallized quartz $(\mathrm{Qu})$ and fine, mica-rich shear zones (5) containing porphyroclasts $(200 \mu \mathrm{m})$; (c) microcline showing edge replacement by radiating aggregates of muscovite $(100 \mu \mathrm{m})$; (d) relict orthoclase porphyroclasts (Or) undergoing reaction in minor shears (S) to muscovite plus quartz $(100 \mu \mathrm{m})$; (e) tightly folded relict muscovite $(100 \mu \mathrm{m})$; (f) relict muscovite showing fracturing and recrystallization to fine, unstrained muscovite $(100 \mu \mathrm{m})$.

\section{Cap de Creus mylonite}

The Cap de Creus mylonite was taken from the Hercynian terrain of the eastern Pyrenees. Coarse pegmatites became deformed and mylonitized in ductile shear zones at a late stage in the Hercynian (Carreras et al., 1977, 1980). Progressive development of mylonite microstructure can be studied by sampling from low to high strain as shown by White et al. (1980, Figure 2). 
Here, only a pegmatite mylonite (Figure 4a) is described as all relevant features are shown.

Porphyroclasts of albite up to $4 \mathrm{~mm}$ diameter are often kinked and preserve large quartz grains with undulatory extinction in strain shadows. Microcline, when in contact with small shear zones containing fine muscovite and quartz, is replaced by radiating aggregates of white mica (Figure 4c, d). Hard quartz is present as porphyroclasts, but usually quartz occurs in bands as recrystallized grains 20-50 $\mu \mathrm{m}$ diameter (Figure $4 \mathrm{~b}$ ). Thin anastomosing shear zones containing fine muscovite + quartz cross cut this rock imparting on it an irregular but marked foliation (Figure 4a). In these zones, small porphyroclasts appear to have been fractured, pulled apart and rotated during shearing. Relict muscovite micas are bent and kinked, and are becoming replaced at their margins by fine, unstrained idiomorphic muscovite (Figure 4e, f).

\section{GEOMETRICAL SOFTENING}

Geometrical softening occurs in a mylonite when grains deforming by intracrystalline slip have their lattices reorientated so that their slip planes lie in or near the plane of shear and their slip directions come to lie parallel to the direction of shear. For example, quartz undergoing basal slip in an "a" direction would become preferentially orientated with c-axes approaching parallelism with the $\mathrm{Z}$ strain axis-at $90^{\circ}$ to the mylonite foliation. A photometric survey of quartz c-axis orientations in the three mylonites was undertaken using the methods of Price $(1973,1978)$ on an instrument described by Williams et al. (1980). Results of this survey are presented in Figure 5, where the circles represent the analysed field of view, the bar represents the mean quartz c-axis orientation, and the figures refer to the estimated number of quartz grains in the field of view. Additionally, c-axis orientations of individual strained quartz porphyroclasts are shown as a bar labelled $\mathrm{C}$. It should be noted that this method is essentially two dimensional, and c-axis orientations in the plane of the section only are shown.

In the Locquirec protomylonite (Figure 5a) large areas of undeformed granitoid remain, and there are numerous, thin, reaction softened zones. Equidimensional quartz porphyroclasts generally have c-axes unfavourably oriented for slip, and these are likely to remain as quartz porphyroclasts through to high strains. The regions of recrystallized quartz exhibit c-axis preferred orientations most commonly at a high angle to the mylonite foliation.

The Arnaboll thrust mylonite (Figure 5b) contains reaction softened zones which define the mylonitic foliation. Elongate plagioclase feldspars (arrowed on Figure 5b) are fractured, and contain recrystallized quartz as fracture infill. 

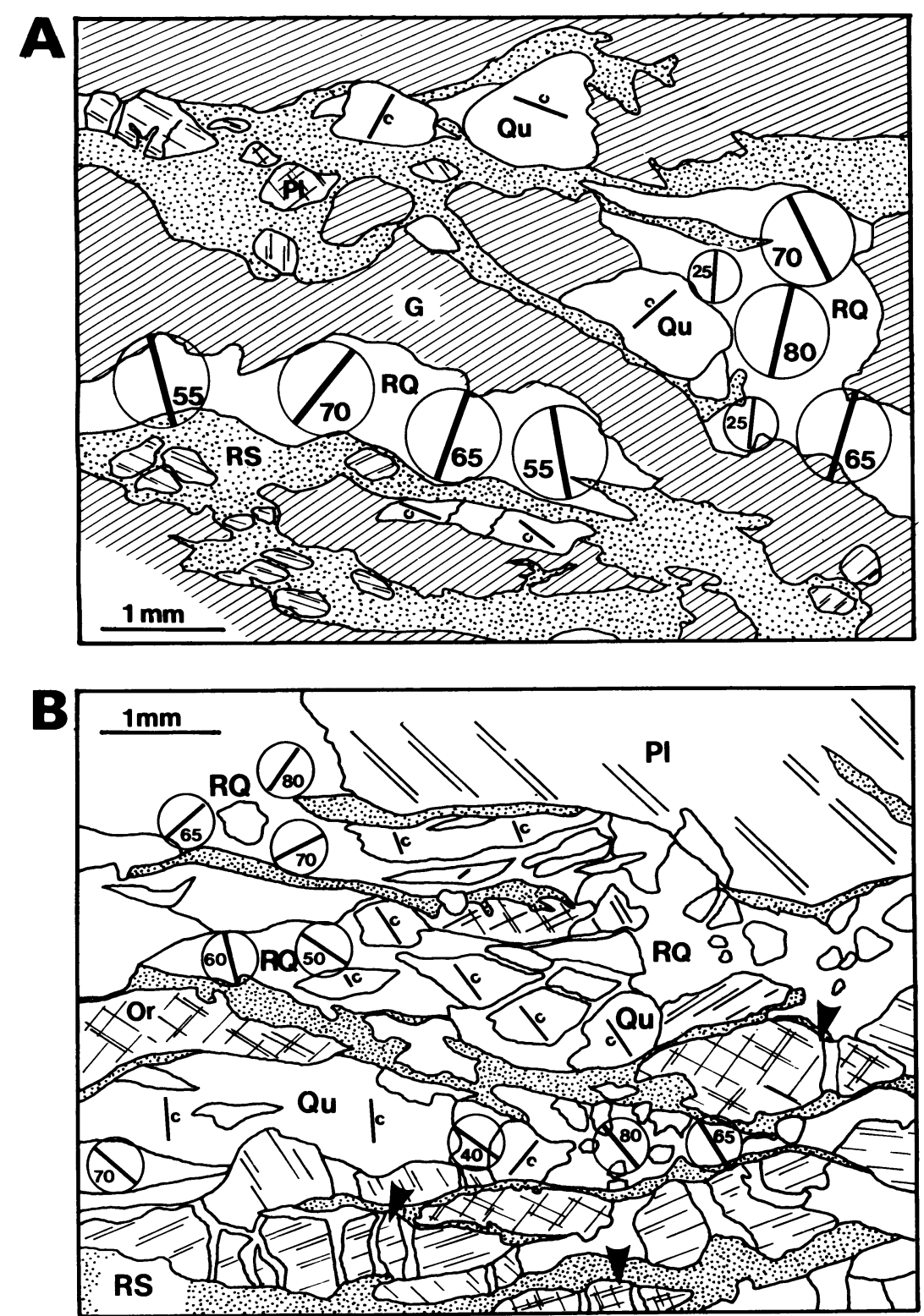

FIGURE 5 Sketches of thin sections with photometric quartz-fabric analyses. (a) Locquirec protomylonite; (b) Arnaboll Nappe mylonite; (c) Cap de Creus mylonite. For all sections, $\mathrm{Qu}$ - strained quartz porphyroclast, $\mathrm{Pl}$ - plagioclase feldspar, $\mathrm{Or}$-orthoclase feldspar, $\mathrm{G}$ - undeformed granitoid rock, RQ-recrystallized quartz, RS-reaction softened zones, $\mathrm{Mu}$ muscovite. Orientation of c-axes of individual quartz porphyroclasts are labelled c. Photometric results - circle is the field of view, the bar is the mean c-axis orientation of quartz grains and the approximate number of grains is quoted in or near the circle. Arrows indicate fractured feldspars. 
Elongate, strained-quartz porphyroclasts have c-axes oriented usually between $60^{\circ}$ and $90^{\circ}$ to the mylonite foliation. Although photometric results from areas of recrystallized quartz are variable, within any one region of the section, c-axis orientations are reasonably consistent. This could reflect the controlling influence of the parent quartz grain on recrystallized grains.

In the Cap de Creus mylonite (Figure 5c), orthoclase, plagioclase and muscovite are common porphyroclasts. There is edge alteration of orthoclase to fine assemblages of quartz and muscovite, and plagioclase is often rimmed by fine grained quartz. There is close agreement of quartz c-axis orientations across this slide, which are commonly at right angles to the mylonite foliation. All three thin sections, and especially Figures 5a and 5c show crystallographic orientations consistent with basal slip in quartz.

From the above description of granitoid mylonite series rocks, it is clear that quartz deforms by intracrystalline slip, at least in the initial stages of deformation. Well developed shape fabrics in quartz grains are a response to the reorientation of grains for easy slip. In materials with limited slip systems, this results in geometric softening of the rock (Dillamore et al., 1979). Experimental work (e.g. Burrows et al., 1979) has shown that geometric softening is normally accompanied by continual recrystallization, which constantly produces new strain-free grains in the developing mylonite. Recrystallized grains can be further deformed by intracrystalline deformation (e.g. Figure $3 f$ ), or, if the recrystallized grain size is sufficiently small, and grains share common

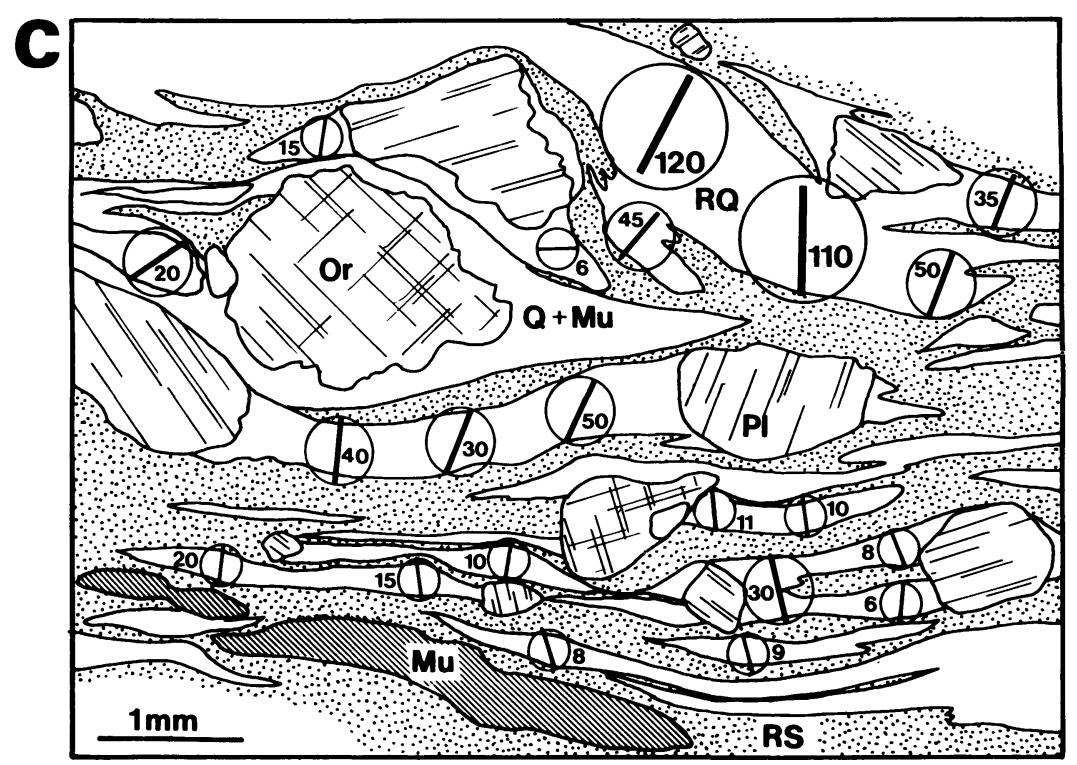


grain boundaries a change in deformation mechanism to grain boundary sliding may cause further softening of the mylonite (White, 1979).

Intracrystalline ductile deformation of plagioclase is indicated by minor kinking of the twins in both the Cap de Creus and Lewisian mylonites. This results in only a minor shape change, and it may be regarded as a strain hardening rather than a softening mechanism. However, in all three mylonites, feldspar is seen to behave in an apparently brittle manner, becoming extensively fractured in the ductile matrix. White (1975) pointed out that feldspars exhibit limited ductility in low temperature mylonites which means that they recrystallize or fracture before exhibiting any marked elongations. Feldspar fractures are often cleavage controlled and may be the result of shear (Allison and Latour, 1978), dislocation pile-up or fibre loading (Kelly, 1968; Goods and Brown 1979). Extensional fractures in feldspars often result in pulling apart of the fragments, and fracture-infilling with quartz. Such brittle fragmentation of porphyroclasts in a ductilely deforming matrix results in significant grain refinement which leads to softening of the mylonite (White, 1976).

Softening processes involving both quartz and feldspar are thought to take place at an early stage of mylonite development, when quartz/feldspar grain contacts are common, and muscovite/sericite is relatively sparse. After initial geometric softening of quartz with associated dynamic recrystallization of quartz and fragmentation of feldspars, a secondary softening process involving metamorphic reactions takes over, and strain concentrates in reaction-softened zones.

\section{REACTION SOFTENING}

Reaction softening or reaction enhanced ductility should be present in rocks undergoing deformation when new grains are generated by metamorphic reactions (White and Knipe, 1978). Softening may be attributed to the release of fluids by dehydration reactions of minerals such as serpentine (Raleigh and Paterson, 1965) or chlorite (Murrell and Ismail, 1976) which results in an increased pore fluid pressure. Alternatively, metamorphic reactions give rise to the production of new, strain-free grains which are more easily deformed than the original grains. White and Knipe (1978) concluded that small, new grains produced by metamorphic reactions may promote superplasticity in a mylonite.

\section{Mineralogical and chemical changes: Locquirec mylonites}

As can be seen from Tables I and II there is a considerable variation in whole rock chemistry and mineralogical content in the Locquirec mylonites. The 
samples indicated are defined as follows: L10 least deformed $(\gamma \leqslant 1)$ of samples, protomylonitic; L3 more deformed $(\gamma \simeq 3)$, mylonitic; L2 most deformed $(\gamma \geqslant 5)$; approaching ultramylonitic.

Clearly the greatest variation occurs between the mylonitic and ultramylonitic stages. The decrease in $\mathrm{SiO}_{2}$ content with increased deformation is accompanied by an increase in quartz content in modal analyses. This, at first sight, may appear to be a contradiction but when the overall $\mathrm{SiO}_{2}$ content is estimated from the modal analyses it can be shown that $\mathrm{SiO}_{2}$ decreases with increased deformation. Both plagioclase and orthoclase occur in most abundance in the least deformed rock sample (L10). The feldspar content is considerably decreased in the mylonitic material (L3) and still further reduced in the ultramylonitic stage. This decrease of feldspar content with deformation is accompanied by a marked increase in muscovite content, and it is extremely likely that the muscovite is developing at the expense of feldspar. The overall effect of the deformation in terms of mineralogy has been to change an assemblage consisting dominantly of quartz and feldspar to one consisting dominantly of quartz and muscovite. During this deformation, chemical processes involving the removal of $\mathrm{SiO}_{2}$ and addition of $\mathrm{K}_{2} \mathrm{O}$ and $\mathrm{FeO}$ have occurred, which to some extent is shown by the increase in the quantity of magnetite and by a marked increase in muscovite content. Compensating this addition of material there is a removal of $\mathrm{CaO}$ and $\mathrm{NaO}$ especially between the mylonitic and ultramylonitic stages, suggesting that during the deformation various reactions involving the addition and subtraction of a variety of components has occurred. It is suggested that the reactions involved were taking place in the presence of some fluid phase, probably water (Beach 1976, 1980).

\section{Metamorphic reactions: Locquirec mylonites}

Any consideration of metamorphic reactions involved in the formation of the Locquirec mylonites must attempt to answer the questions of addition and subtraction of material posed by the geochemical analyses together with a consideration of the resulting mineralogy. In general the assemblage in the deformed rocks of muscovite and quartz with minor amounts of chlorite and biotite suggest greenschist conditions representing the degradation of the original granitoid assemblage. From the modal analyses of the mylonites it has been suggested that the increase in muscovite content is linked directly to the decrease in feldspar content, and the increase in $\mathrm{K}_{2} \mathrm{O}$ and a decrease in $\mathrm{Na}_{2} \mathrm{O}$ (Table I) suggests that plagioclase $\left(\mathrm{NaAlSi}_{3} \mathrm{O}_{8}\right)$ has acted as a source for $\mathrm{Al}$. This possibility would lead to a reaction which may be represented as:

$2 \mathrm{KAlSi}_{3} \mathrm{O}_{8}+4 \mathrm{NaAlSi}_{3} \mathrm{O}_{8}+4 \mathrm{H}^{+} \Rightarrow \mathrm{K}_{2} \mathrm{Al}_{4} \mathrm{Si}_{6} \mathrm{Al}_{2} \mathrm{O}_{20}(\mathrm{OH})_{4}+4 \mathrm{Na}^{+}+12 \mathrm{SiO}_{2}$ 
Clearly this reaction allows for the breakdown of two feldspars to form muscovite and $\mathrm{Na}^{+}$becomes available for removal. Quartz is released by the reaction and, as there is an overall decrease in bulk silica content it may be this reaction that produces the necessary material for removal. Some system such as Eq. 2 may be envisaged:

$\mathrm{SiO}_{2}+2 \mathrm{H}_{2} \mathrm{O} \leftrightharpoons \mathrm{H}_{4} \mathrm{SiO}_{4} \leftrightharpoons \mathrm{H}_{3} \mathrm{SiO}_{4}^{-}+\mathrm{H}^{+}$ (after Beach 1980).

However, reaction (1) does not show the influence of additional $\mathrm{K}^{+}$in the system which may be considered by modifying the above reaction (1) to give: $\mathrm{KAlSi}_{3} \mathrm{O}_{8}+5 \mathrm{NaAlSi}_{3} \mathrm{O}_{8}+4 \mathrm{H}^{+}+\mathrm{K}^{+} \Rightarrow$

$$
\mathrm{K}_{2} \mathrm{Al}_{4} \mathrm{Si}_{6} \mathrm{Al}_{2} \mathrm{O}_{20}(\mathrm{OH})_{4}+12 \mathrm{SiO}_{2}+5 \mathrm{Na}^{+}
$$

This gives a close agreement to the percentage $\mathrm{K}_{2} \mathrm{O}$ increase observed in Table I from low to high strain. Reaction 3, however, suggests the necessity for the mixing of orthoclase and plagioclase in the ratio of $1: 5$ to allow the reaction to proceed; a fact not readily confirmed by modal analyses (Table II). This reaction suggests that excess plagioclase is required for completion though there appears to be no significant difference in the quantities of plagioclase and orthoclase in undeformed rocks. The necessary equal proportions as observed in the modal analyses can be shown to produce muscovite if the following is considered.

$$
3 \mathrm{KAlSi}_{3} \mathrm{O}_{8}+3 \mathrm{NaAlSi}_{3} \mathrm{O}_{8}+\underset{\mathrm{K}_{2} \mathrm{Al}_{4} \mathrm{Si}_{6} \mathrm{Al}_{2} \mathrm{O}_{20}(\mathrm{OH})_{4}+\mathrm{K}^{+}+3 \mathrm{Na}^{+}+12 \mathrm{SiO}_{2}}{4 \mathrm{H}^{+}}
$$

Reactions of the types 1 to 4 give some idea of the removal of $\mathrm{Na}^{+}$and production of $\mathrm{SiO}_{2}$ which may be removed. In the calcic component of plagioclase feldspar, the following reaction may be considered:

$2 \mathrm{KAlSi}_{3} \mathrm{O}_{8}+2 \mathrm{CaAl}_{2} \mathrm{Si}_{2} \mathrm{O}_{8}+4 \mathrm{H}^{+}=\mathrm{K}_{2} \mathrm{Al}_{4} \mathrm{Si}_{6} \mathrm{Al}_{2} \mathrm{O}_{20}(\mathrm{OH})_{4} 4 \mathrm{SiO}_{2}+2 \mathrm{Ca}^{2+}$

This again shows the total removal of $\mathrm{Ca}^{2+}$ and the production of $\mathrm{SiO}_{2}$ some of which may be removed.

From reactions 3 and 5 the following results:

$$
\begin{aligned}
3 \mathrm{KAlSi}_{3} \mathrm{O}_{8}+5 \mathrm{NaAlSi}_{3} \mathrm{O}_{8}+2 \mathrm{CaAl}_{2} \mathrm{Si}_{2} \mathrm{O}_{8}+\mathrm{K}^{+}+8 \mathrm{H}^{+}= \\
2 \mathrm{~K}_{2} \mathrm{Al}_{4} \mathrm{Si}_{6} \mathrm{Al}_{2} \mathrm{O}_{20}(\mathrm{OH})_{4}+16 \mathrm{SiO}_{2}+5 \mathrm{Na}^{+}+2 \mathrm{Ca}^{2+}
\end{aligned}
$$

A ratio of $5: 2$ for plagioclase $\mathrm{Na}$ : Ca content gives an $\mathrm{Ab}$ value of $71 \%$ which gives plagioclases in the calcic oligoclase-andesine region. The plagioclase in the undeformed rock is approximately of this composition and it is believed that Eq. (6) is a reasonable description of the reaction taking place in the Locquirec mylonites during deformation.

All of the above reactions produce appreciable quantities of quartz, and it is believed that some $\mathrm{SiO}_{2}$ may have been removed as the reactions proceeded. However, some may have been able to form soft, strain-free grains 
TABLE I

Major element whole rock analyses, Locquirec mylonites. Approximate shear strain values given in brackets. LOI $=$ Loss on ignition.

\begin{tabular}{|c|c|c|c|c|}
\hline & & $L 10(\gamma<2)$ & $L 3(\gamma \simeq 3)$ & $L 2(\gamma>5)$ \\
\hline $\mathrm{SiO}_{2}$ & & 71.38 & 70.39 & 66.81 \\
\hline $\mathrm{Al}_{2} \mathrm{O}_{3}$ & & 14.79 & 14.73 & 15.62 \\
\hline $\mathrm{TiO}_{2}$ & & 0.22 & 0.28 & 0.22 \\
\hline $\mathrm{Fe}_{2} \mathrm{O}_{3}{ }^{\mathrm{a}}$ & & 3.04 & 2.46 & 8.24 \\
\hline $\mathrm{MgO}$ & & 0.84 & 1.06 & 0.65 \\
\hline $\mathrm{CaO}$ & & 0.27 & 0.18 & 0.00 \\
\hline $\mathrm{Na}_{2} \mathrm{O}$ & & 3.99 & 4.01 & 0.22 \\
\hline $\mathrm{K}_{2} \mathrm{O}$ & & 2.58 & 3.86 & 5.45 \\
\hline $\mathrm{MnO}$ & & 0.02 & 0.02 & 0.08 \\
\hline $\mathrm{P}_{2} \mathrm{O}_{5}$ & & 0.08 & 0.10 & 0.05 \\
\hline \multirow[t]{2}{*}{ LOI } & & 1.89 & 2.08 & 2.41 \\
\hline & TOTAL & 99.10 & 99.08 & 99.75 \\
\hline
\end{tabular}

$\left({ }^{\mathbf{a}}\right.$ Total $\mathrm{Fe}$ as $\left.\mathrm{Fe}_{2} \mathrm{O}_{3}\right)$

TABLE II

Modal analyses, Locquirec mylonites. All figures as percentage based on 1000 points. $P$ indicates mineral present in small quantity.

\begin{tabular}{lccc}
\hline & $L 10(\gamma<2)$ & $L 3(\gamma \simeq 3)$ & $L 2(\gamma>5)$ \\
\hline Quartz & 39 & 41.7 & 45.25 \\
Plagioclase & 18.3 & 8.3 & 3.25 \\
Orthoclase & 14 & 7.5 & 4.75 \\
Muscovite & 19.3 & 34.0 & 44.25 \\
Biotite & 4.7 & 8.1 & $\mathbf{P}$ \\
Chlorite & 3.7 & $\mathrm{P}$ & $\mathrm{P}$ \\
Magnetite & 1.0 & 0.3 & 2.25 \\
Clays & $\mathrm{P}$ & $\mathrm{P}$ & $\mathrm{P}$ \\
Epidote & $\mathrm{P}$ & 0.1 & $\mathrm{P}$ \\
\hline
\end{tabular}

of small dimensions which will then have played an important role in the further softening of the rock (White and Knipe, 1978).

The increase in iron content and the sharp decrease in biotite as the rock becomes highly deformed is likely to involve the leaching of biotite to form muscovite (Deer et al., 1962) as shown in Eq. (7).

$\mathrm{K}_{2} \mathrm{Fe}_{6} \mathrm{Si}_{6} \mathrm{Al}_{2} \mathrm{O}_{20}(\mathrm{OH})_{4}+4 \mathrm{NaAlSi}_{3} \mathrm{O}_{8}+2 \mathrm{H}_{2} \mathrm{O}=$

$\mathrm{K}_{2} \mathrm{Al}_{4} \mathrm{Si}_{6} \mathrm{Al}_{2} \mathrm{O}_{20}(\mathrm{OH})_{4}+12 \mathrm{SiO}_{2}+4 \mathrm{Na}(\mathrm{OH})+2 \mathrm{Fe}^{2+}+4 \mathrm{Fe}^{3+}+30_{2}$

This reaction shows the breakdown of biotite and plagioclase though orthoclase could be substituted. The disadvantage of using orthoclase is the likeli- 
hood of the removal of $\mathrm{K}_{2} \mathrm{O}$ and thus $\mathrm{Na}$-feldspar is preferred. Iron is released in this reaction and this may, in part, account for the increase in magnetite in the modal analyses though the addition of iron from exterior sources indicated by whole rock chemistry must also be important in high strains. The iron and oxygen may recombine to form magnetite as follows:

$\mathrm{Fe}^{2+}+2 \mathrm{Fe}^{3+}+4 \mathrm{O}^{2-} \leftrightharpoons \mathrm{FeO}^{2} \mathrm{Fe}_{2} \mathrm{O}_{3}$

For the above reactions to take place, and for the removal of $\mathrm{SiO}_{2}$, large quantities of water are required. From the data of Fyfe et al. (1978) it can be calculated that $26 \times 10^{11} \mathrm{~m}^{3}$ of water would be required for $\mathrm{SiO}_{2}$ removal on this scale (assuming greenschist conditions). This water would probably be concentrated in the narrow zones and is in keeping with the ideas of Beach (1980) and Sibson et al. (1975) concerning seismic pumping. In effect the shear zone acts as a sink for surrounding fluids contained in the rock during stress increase. Clearly the supply of large quantities of fluids assist the reactions and Beach (1980) suggests that metamorphic reactions take place early and play minimal part in the development of the shear zone as deformation continues. Early stages of the above reactions can be seen in the undeformed or least deformed rocks at Locquirec though always the disappearance of feldspar is accompanied by highest deformation. This suggests that the deformation and metamorphism proceed together, though this does not necessarily preclude further deformation, in what would be a softened zone, without any further metamorphic reaction.

\section{Reaction softening in Ben Arnaboll and Cap de Creus mylonites}

The Ben Arnaboll protomylonite shows microstructural evidence which suggests some degree of reaction softening. Mica development is evident and forms an anastomosing fabric within the rock. The mica, usually muscovite, occurs as very small grains and it is likely that it has formed largely as a result of the decay of feldspars (Eq. (6)). This fact is supported by clear evidence of sericitization within the rock. It would appear that reaction softening has played a secondary role to the process of geometric softening and continued recrystallization. Quartz has undergone considerable deformation and usually exhibits core and mantle structures. Feldspars appear to have been behaving as brittle solids in a ductile medium and this has probably enhanced what reaction softening has occurred simply by presenting a greater surface area suitable for reaction. The fact that fluids are required for reaction softening may suggest that the fluid content was too low for the necessary reactions to take place over the whole rock, hence reactions are restricted to numerous, narrow anastomising high strain zones.

Ultramylonitic material from Ben Arnaboll, however, shows a considerable 
development of muscovite as small idiomorphic grains. There has been a complete or almost complete removal of feldspar, and a considerable reduction in the grain size of quartz. This suggests that both reaction and geometric softening has taken place and also that the development of small mica flakes has inhibited the growth of quartz grains; this in turn may have softened the rock by aiding grain boundary sliding. It would appear that the effect of the reactions has been twofold. Firstly, it has had the effect of reducing grain size by producing small strain-free micas from large often strained feldspar grains. Secondly, the presence of small micas has had the effect of maintaining a reduced quartz grain size and thus enhancing grain bcundary sliding.

The Cap de Creus mylonites show considerable evidence for a process involving reaction softening. In the early stages quartz deforms plastically and has associated dynamic recrystallization. Feldspar is preserved at this stage and primary mica shows evidence for intracrystalline deformation and recrystallization. It seems likely that here, once again, the brittle behaviour of feldspar has assisted reaction softening by a process close to Eq. (6). The ultramylonitic material is similar to that of the Ben Arnaboll and Locquirec ultramylonites in that the main feature is a rather fibrous mass of idiomorphic white mica. Within this mass are minute quartz grains pinned by the mica and hence a fine grain size is maintained. Small quantities of feldspar remain and these have continued to behave as brittle solids, the cracking of which has aided in the grain size reduction.

In summary, metamorphic reactions involving feldspar breakdown to muscovite + quartz can be seen to have two effects leading to softening of the rock:

1) The production of a soft assemblage of muscovite plus quartz. This assemblage is soft because:

a) newly-formed, strain-free grains are capable of further deformation. micas.

b) quartz grain growth is inhibited by the pinning effect of idiomorphic

2) The reduction of overall grain size by degradation of feldspar.

\section{CONCLUSIONS}

It is clear that in the three granitoid mylonites discussed, strain is concentrated in their shear zones by two distinct softening processes. An early period of geometric softening takes place when quartz/feldspar grain contacts are common. Geometric softening is shown by fabric studies which suggest intra- 
crystalline deformation of quartz and its associated continual dynamic recrystallization. Feldspars undergo grain refinement by brittle fragmentation in a ductile matrix. Reaction softening is a secondary process which takes place at higher strains, and is a result of the migration of fluids in the shear zones. $\mathrm{K}$ feldspar and plagioclase is broken down to the softer and fine grained assemblage muscovite plus quartz. Deformation is further concentrated into these reaction softened zones, and this permits coarse plagioclase feldspar grains to act in a brittle fashion in a highly ductile matrix of fine idiomorphic muscovite + quartz. Fluid mobility in mylonites enhances reaction softening which, in turn, concentrates deformation into the shear zone. It is likely that the reactions described here are more common in deformed granitoid rocks than previously thought.

\section{Acknowledgements}

We should like to thank Stan White for helpful comments, and our colleagues at University College, Cardiff for valuable discussion. Fieldwork was carried out during a NERC studentship (JD) and GDW acknowledges receipt of a U.C.C. travel grant. Chemical analyses were carried out by the Nottingham University XRF Unit.

\section{References}

Allison, I. and Latour, T. B. Brittle deformation of hornblende in a mylonite. Can. J. Earth Sci. 14, 1953-58 (1977).

Beach, A. The interrelations of fluid transport, deformation, geochemistry and heat flow in early Proterozoic shear zones in the Lewisian Complex. Phil. Trans. Roy. Soc. A280, 569-604 (1976).

Beach, A. Retrogressive metamorphic processes in shear zones with special reference to the Lewisian Complex. J. Struct. Geol. 2, 25-50 (1980).

Bouchez, J. L. Plastic deformation of quartzites at low temperature in an area of natural strain gradient. Tectonophysics 39, 257-263 (1977).

Burrows, S. E., Humphreys, F. J. and White, S. H. Dynamic recrystallization and textural development in magnesium deformed in compression at elevated temperatures. 5th Int. Conf. on Strength of Metals and Alloys, Aachen 607-615 (1979).

Carreras, J., Estrada, A. and White, S. The effects of folding on the c-axis fabric of quartz mylonite. Tectonophysics 39, 3-24 (1977).

Carreras, J., Julivert, M. and Santanach, P. Hercynian mylonite belts in the eastern Pyrenees. J. Struct. Geol. 2, 5-9 (1980).

Coward, M. P. The Caledonian thrust and shear zones of NW Scotland. J. Struct. Geol. 2, 11-17 (1980).

Deer, W. A., Howie, R. A. and Zussman, J. An Introduction to the rock forming minerals. Longman, London, $528 \mathrm{pp}$ (1966).

Dillamore, I. L., Roberts, J. G. and Bush, A. C. Occurrence of shear bands in heavily rolled cubic metals. Met. Sci. J. 13, 73-77 (1979).

Fyfe, W. S., Price, N. J. and Thompson, A. B. Fluids in the Earth's Crust. Elsevier, Amsterdam (1978).

Goods, S. H. and Brown, L. M. The nucleation of cavities by plastic deformation. Acta. Metall. 27, 1-15 (1979).

Kelly, A. Particle and fibre reinforcement. In: Kelly, A. and Nicholson, R. B. (eds.) Strengthening Methods in Crystals. Elsevier. 433-484 (1968). 
McClay, K. R. and Coward, M. P. The Moine Thrust Zone: an overview. In: McClay, K. R. and Price, N. J. (eds.) Thrust and Nappe Tectonics. Geol. Soc. London Spec. Publ. No. 9, 241-260 (1981)

Murrell, S. A. F. and Ismail, I. A. H. The effect of decomposition of hydrous minerals on the mechanical properties of rocks at high pressures and temperatures. Tectonophysics 31, 207-258 (1976).

Poirier, J. P. Shear localization and shear instability in materials in the ductile field. J. Struct. Geol. 2, 135-142 (1980).

Price, G. P. The photometric method in microstructural analysis. Am. J. Sci. 273, 523-537 (1973)

Price, G. P. Study of heterogeneous fabric and texture within a quartz-feldspar mylonite using the photometric method. Bull geol. Soc. Am. 89, 1359-1372 (1978).

Raleigh, C. B. and Paterson, M. S. Experimental deformation of serpentine and its tectonic implication. J. Geophys. Res. 70, 3965-3985 (1965).

Sibson, R. H. Fault rocks and fault mechanisms. J. Geol. Soc. London 133, 191-213 (1977).

Sibson, R. H., Moore, J. Mc.M. and Rankin, A. H. Seismic pumping-a hydrothermal fluid transport mechanism. J. Geol. Soc. Lond. 131, 653-659 (1975).

Tullis, J. A., Christie, J. M. and Griggs, D. T. Microstructures and preferred orientations of experimentally deformed quartzites. Bull. geol. Soc. Am. 84, 297-314 (1973).

Watts, M. J. Shear zone deformation in the Guingamp area, N. Brittany. Unpub. Ph.D. thesis. Univ. Wales, $349 \mathrm{pp}(1980)$.

Watts, M. J. and Williams, G. D. Fault rocks as indicators of progressive shear deformation in the Guingamp region, Brittany. J. Struct. Geol. 1, 323-332 (1979).

White, S. Tectonic deformation and recrystallization of oligoclase. Contrib. Mineral. Petrol. 50, 287-304 (1975).

White, $\mathrm{S}$. The effects of strain on the microstructures, fabrics and deformation mechanisms in quartzites. Phil. Trans. Roy. Soc. London A238, 69-86 (1976).

White, S. Sub-grain and grain size variations across a shear zone. Contrib. Mineral. Petrol. 70, 193-202 (1979).

White, S. H. and Knipe, R. J. Transformation and reaction-enhanced ductility in rocks. J. Geol. Soc. London 135, 513-516 (1978).

White, S. H., Burrows, S. E., Carreras, J., Shaw, N. D. and Humphries, F. J. On mylonites in ductile shear zones. J. Struct. Geol. 2, 175-187 (1980).

Williams, G. D., Share, J. and Watts, M. J. Photometric analyses for crystallographic orientations in rock thin-sections. J. Phys. E: Sci. Instrum. 13, 168-169 (1980). 